\title{
Manufacture Method and Mechanical Properties of Composite Material based on Natural Mineral Fibres and Biodegradable Resin
}

\author{
Thomas WITTEK $^{\mathrm{a},{ }^{*},}$ TANIMOTO Toshio ${ }^{\mathrm{b}}$, MAEKAWA Zenichiro $^{\mathrm{c}}$ \\ ${ }^{a}$ Graduate School of Engineering, Shonan Institute of Technology, \\ 1-1-25 Tsujido-Nishikaigan, Fujisawa, Kanagawa 251-8511, Japan \\ ${ }^{\mathrm{b}}$ Department of Materials Science and Engineering, Shonan Institute of Engineering, \\ 1-1-25 Tsujido-Nishikaigan, Fujisawa, Kanagawa 251-8511, Japan \\ ' Department of Life Welfare, Heian Jogakuin (St.Agnes') University, \\ 5-81-1 Nanpeidai, Takatsuki, Osaka 569-1042, Japan
}

Received 27 December 2007; accepted for publication 2 October 2008

\begin{abstract}
Environmental problems caused by extensive use of polymeric materials arise mainly owing to lack of landfill space and depletion of finite natural resources of fossil raw materials like petroleum or natural gas. The substitution of synthetic petroleum-based resins with natural biodegradable resins appears to be one appropriate measure to remedy the above-mentioned situation.

This study presents the development of a composite that uses environmentally degradable starch-based resin as matrix and natural mineral basalt fibres as reinforcement. Unidirectional prepreg-sheets using basalt fibre roving and bidirectional sheets using plain weave fabric were manufactured by means of a modified doctor blade system and hot power press. The sheets were used to manufacture specimens with fibre volume contents ranging from $33 \%$ to $61 \%$. The composite's mechanical properties were investigated depending on modifications to the processing method and on variation of the fibre volume fraction. Composites manufactured during this study exhibited tensile and flexural strength of up to $517 \mathrm{MPa}$ and $157 \mathrm{MPa}$, respectively.
\end{abstract}

Key Words: Natural mineral fibres, Biodegradable resin, Processing method, Tensile properties, Flexural properties

\section{天然鉱物繊維素材と生分解性樹脂から構成される複合材料の 成形方法と機械的特性}

Thomas WITTEK $^{\mathrm{a},{ }^{*}}$, 谷本敏夫 ${ }^{\mathrm{b}}$, 前川善一郎 ${ }^{\mathrm{c}}$

${ }^{a}$ 湘南工科大学大学院工学研究科, ${ }^{b}$ 湘南工科大学材料工学科, ${ }^{c}$ 平安女学院大学生活福祉学科

\section{1. 緒 言}

近年，プラスチックの過剩使用に伴い，様々な環境問題が 生じている。プラスチックの廃裹処理には一般に, 多くのエ ネルギーを消費するため, 環境に悪影響を及ぼさない廃棄処 理法の開発は，目下の急務となっている．たとえば，プラス チックをゴミ焼却施設で処理した場合, 高エネルギーが消費 されるうえ，有害物質が撒き散らされることとなる。また，
プラスチックは生分解できないため, 土中での埋め立て処理 は有効ではない.

プラスチック系複合材料の将来は，有限な天然石油資源の 枯渴化, 地球温暖化の促進, 有害ガスの排出, そして野生生 物と海洋生物への被害など，広い観点に立脚して考えなけれ ばならない段階にきていると言えるであろう。

無機人造繊維強化複合材料の代替材料を，新規に創製する ことによりこれらの課題を解決する見地から，世界中でグリー

* 連絡先：湘南工科大学大学院工学研究科材料工学専攻 251-8511 神奈川県藤沢市辻堂西海岸 1-1-25

E-mail: wittek@mate.shonan-it.ac.jp, Tel: +81-466-34-4111, Fax: +81-466-36-1594 
ンコンポジットについての研究と技術開発が盛んに行なわれ るようになった。グリーンコンポジットの定義は現時点では 必ずしも統一されていないが，文献[1]によれば，完全もし くは部分的に再生可能な資源由来の構成要素から構成される 複合材料のことであると解釈できる. この定義は母材と強化 材の両方の素材に当てはまることである. また本定義におけ るグリーンコンポジットのキーワードは生分解性である.し たがって, グリーンコンポジットとしての生分解性複合材料 は, 生分解性ポリマーと天然繊維から構成されているのが最 も望ましいことは言うまでもない。

自然サイクル内のコンポスト化, 化石由来資源の保護, 二 酸化炭素排気量の削減による大気污染負荷軽減等は, 従来の プラスチック系複合材料の代替としてグリーンコンポジット を使用することによって得られる最大のメリットである[2].

環境に対する悪影響が強化繊維よりむしろ, 従来のポリマー マトリックスから生じていることは既に周知の事実である. そのような見地に立ち, 本研究では, 従来の石油由来樹脂マ トリックスに替え, 生分解性樹脂をマトリックスとし, 強化 材に天然の鉱物繊維であるバサルト繊維を用いたグリーンコ ンポジットとしてのFRPの新規成形方法を開発し, そのFRP の機械的特性を評価したので報告する.

\section{2. 試験方法}

\section{1 樹 脂}

澱粉はさまざまな植物と微生物に顆粒として存在するエネ ルギー貯蔵材料であり, 穀類（トウモロコシ, 小麦, 米), 塊茎（ジャガイモ）または根（夕ピオカ）から抽出できる, 澱粉顆粒を可塑剤と共に水性媒体中で加熱すると, 顆粒の不 可逆的膨潤により澱粉の糊化が生じる. その結果アミロース が顆粒から溶解し, アミロペクチンが完全に水和し, 澱粉の 可溶化が起こる. 澱粉製品の乾湿性および脆性が高いため, 費用対効果条件が満たされる加熱塑性澱粉樹脂を得るよう, 澱粉の修飾または他材料との混合が必要である[3].

高い繊維含有率を有する複合材料を開発目標とするため, マトリックス材として水分散型修飾澱粉生分解性樹脂（ラン ディーCP-300, (株) ミョシ油脂製) を用いた. 水を分散媒体と して使用したエマルジョンには, 天然脂肪酸で変性した $5 \mu \mathrm{m}$ の平均直径の澱粉粒子が分散されている [4]. マニラ麻[5], クラウア[6]などの植物繊維を使用したCP-300の応用例があ る. 使用した樹脂の特性を Table 1 に示す.

Table 1 Properties of starch resin CP-300.

\begin{tabular}{l|c}
\hline Density $\left[\mathrm{g} / \mathrm{cm}^{3}\right.$ ] & 1.17 \\
\hline Tensile strength [MPa] & 8.3 \\
\hline Tensile elongation [\%] & 16.8 \\
\hline Modulus of elasticity [GPa] & 0.3 \\
\hline
\end{tabular}

\section{2 植物繊維とバサルト繊維}

天然の植物繊維は起源によって数種類に分類される (Fig. 1). 現在, グリーンコンポジット作製に使用される緎 維のほとんどはセルロース系植物繊維である。セルロース系 天然繊維は, 低費用, 低比重, 高比強度, 生分解性など多く の長所を有するが, 反面, 欠点をも併せ持っている. 繊維の 膨潤によってもたらされる吸湿, 低い熱抵抗, 栽培場所や季 節による品質の変動, 低い圧縮及び横方向強度は植物繊維の 短所である[7].

本研究では, 強化材として, ロシアのSudaglass Fiber Technology Inc.製のバサルトロービング（BS-13-1200，単繊

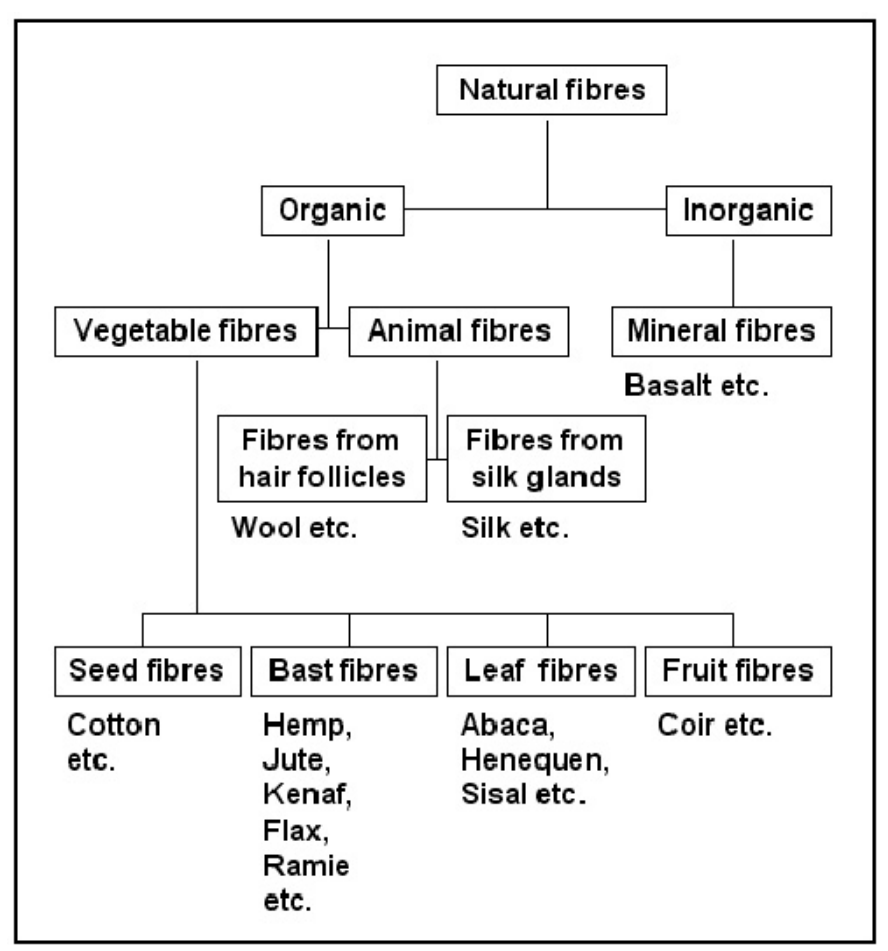

Fig. 1 Classification of natural fibres (according to JIS L 0204-1: 1998).

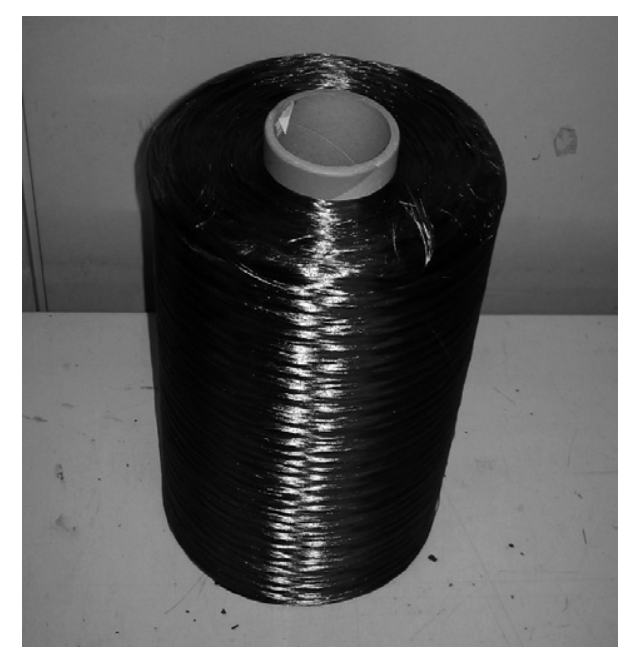

Fig. 2 Basalt roving (BS-13-1200, Sudaglass Fiber Technology Inc). 


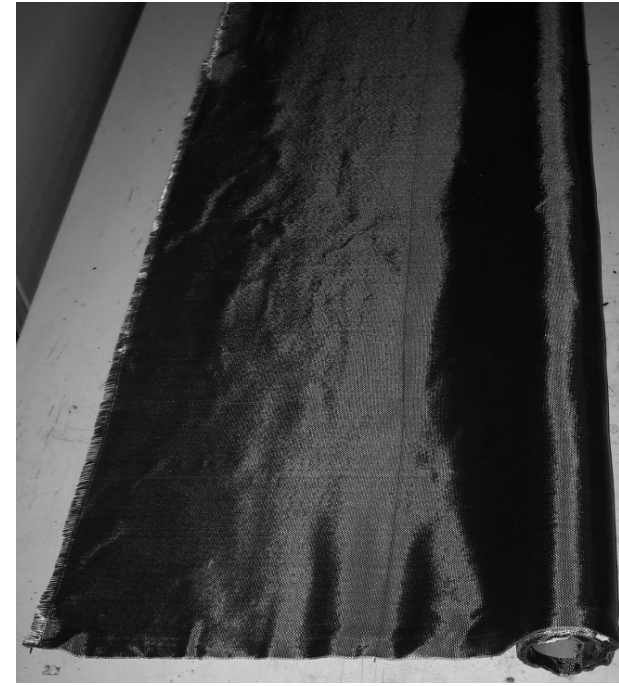

Fig. 3 Basalt plain weave (BT-8, Sudaglass Fiber Technology Inc).

Table 2 Comparison of mechanical properties of several synthetic and natural fibres.

\begin{tabular}{|c|c|c|c|c|c|}
\hline Material & $\begin{array}{c}\text { Density } \\
{\left[\mathrm{g} / \mathrm{cm}^{3}\right]}\end{array}$ & $\begin{array}{c}\text { Tensile } \\
\text { strength [MPa] }\end{array}$ & $\begin{array}{c}\text { Modulus of } \\
\text { elasticity [GPa] }\end{array}$ & $\begin{array}{c}\text { Elongation at } \\
\text { break [\%] }\end{array}$ & Reference \\
\hline Basalt & 2.7 & $1430-3470$ & $86-92$ & $2.1-3.3$ & {$[9-12]$} \\
\hline E-Glass & 2.5 & $2000-3430$ & $70-73$ & $2.5-3.1$ & {$[14-16]$} \\
\hline Flax & 1.5 & $345-1100$ & 28 & $2.7-3.2$ & {$[16]$} \\
\hline Sisal & 1.5 & $468-640$ & $9.4-22$ & $1.2-3.8$ & {$[16]$} \\
\hline
\end{tabular}

維直径 $13 \mu \mathrm{m} ， 1200$ tex）（Fig. 2）およびバサルト平織クロス (BT-8, 質量 $210 \mathrm{~g} / \mathrm{m}^{2}$, 厚さ $0.18 \mathrm{~mm}$, 縦密度 $10 \mathrm{yarns} / \mathrm{cm}$, 横 密度 8 yarns $/ \mathrm{cm}$ )（Fig. 3）を用いた.

バサルト繊維は火成岩の一種の立武岩から製造されてい る. 玄武岩の主成分は酸化珪素 $\left(\mathrm{SiO}_{2}\right)$ であり, $\mathrm{Al}_{2} \mathrm{O}_{3}$ およ び $\mathrm{Fe}_{2} \mathrm{O}_{3}, \mathrm{FeO}, \mathrm{CaO}, \mathrm{MgO}$ な゙が残りの成分を占める. バ サルトは $\mathrm{SiO}_{2}$ の重量率によりアルカリ性 (42\%以下), 弱酸 性（43\%～46\%） および酸性（46\% 以上）に分類され，酸性 バサルトのみが繊維化要件を満たす [8]。バサルト纎維はさ まざまな成分がバサルトに最初から存在するので, 添加物を 使用しない溶融工程を用いて玄武岩原石から押し出し工程を 経て紡糸される。したがって，バサルト纎維は比較的経済的 な製品である。また，バサルト繊維は遮音性及び断熱特性， 難燃性に優れ, かつ機械的強度においても優れた特性を有し， ガラス繊維や植物繊維と比較しても, ほぼ同等の機械的特性 を示す（Table 2).ささらに，バサルト繊維はいかなる物理的 状況下でも発癌物質などの有害物質を排出することがなく, 環境的に無害な製品であることが知られている[13].

\section{3 試験片製作}

試験片の成形過程において2種類の加工装置を使用した。 成形過程の第一段階において䋊維にマトリックスを含浸させ たプリプレグシートを作った. プリプレグの成形工程を機械 化し信頼性を確保するため，ドクターブレード装置（DP-

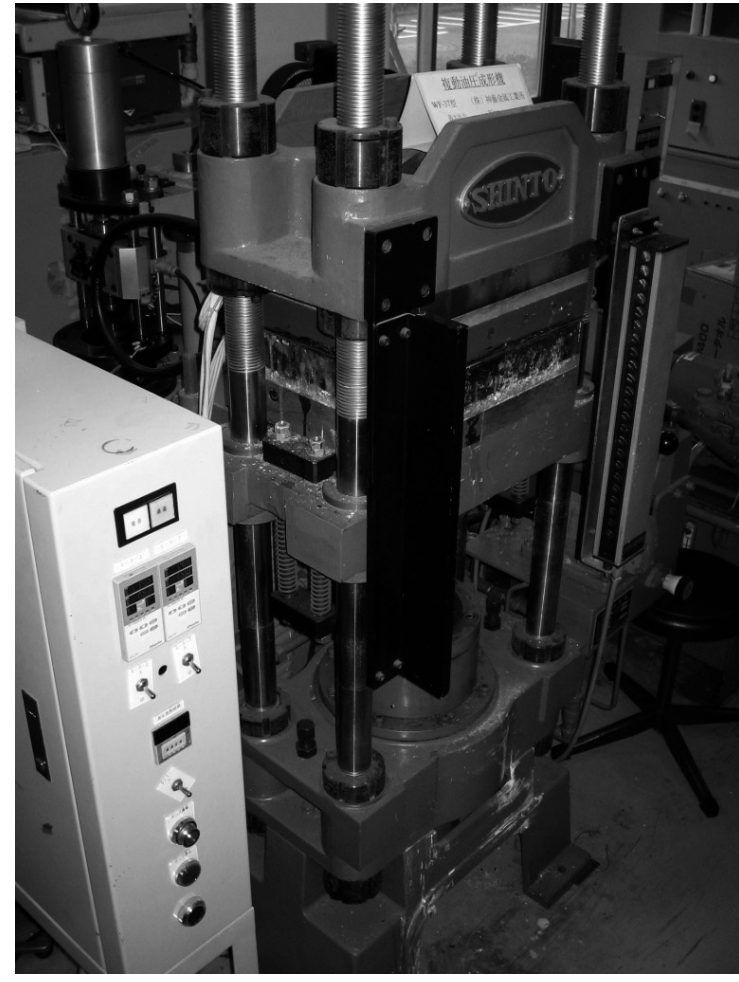

Fig. 4 Hot power press (WF-37, Shinto Co.).

150，（有)津川精機製作所）を使用した製造工程を開発した。 一方向に引き揃えた繊維中へのマトリックスの含浸の工程を 経て得られた予備シートから，ホットプレス装置（WF-37, (株) 新藤金属工業所）（Fig. 4）を用いて加圧加熱によりプリ プレグシートを作る。

ドクターブレード装置（Fig. 5）は，ドクターブレード部 とプラスチックキャリアフィルム上で繊維に樹脂を含浸させ たプリプレグシートを電動駆動装置によって連続的に移動さ せる架台部から構成される，ドクターブレード部には先端部 にテーパーのついた2枚のブレードがあり，液ダムから常に 一定の樹脂量が流れ出て，引き揃えた繊維に均一に樹脂を含 浸させることが出来るように, 液ダムから樹脂の流れ出る出 口の隙間を 2 枚のブレードによって2段のステップで均一に 調整できるようになっている.

繊維をキャリアシート上で引き揃え，水分散型樹脂を液夕゙

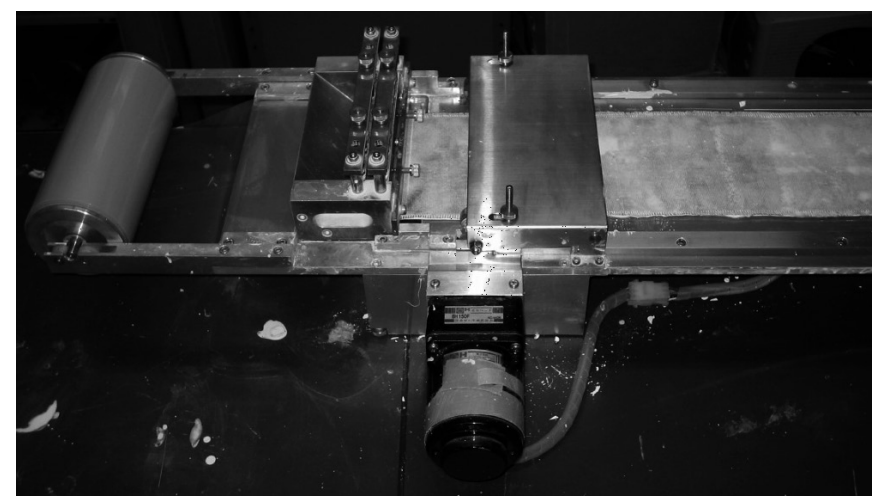

Fig. 5 Doctor blade system (Tsugawa Seiki Seisakusho Ltd.). 


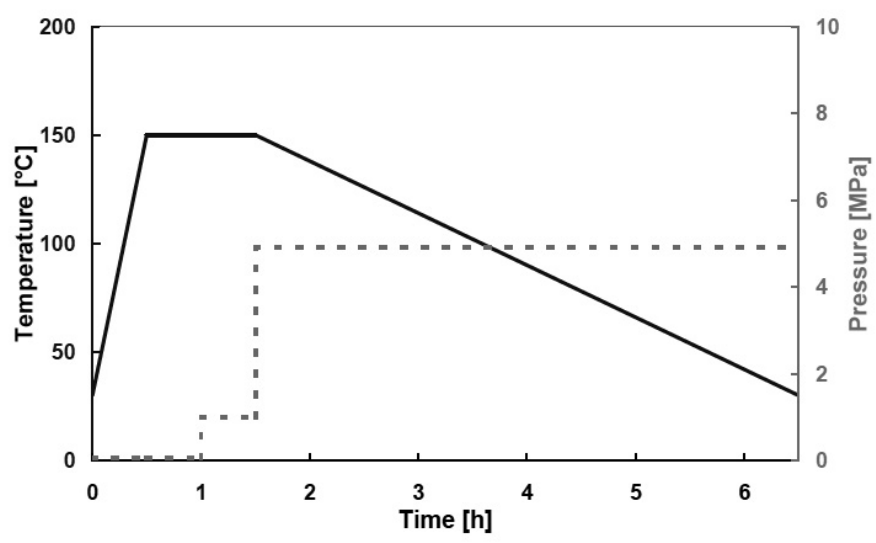

Fig. 6 Moulding process chart.

ムに流しながら， $30 \mathrm{~cm} / \mathrm{min}$ の速度で移動させられるキャリ アシート上で繊維に樹脂を含浸させる。その後，16時間乾 燥させた後切断した予備シートから加熱加圧工程（プリプレ グ成形）を経て，プリプレグシートが成形される。プリプレ グシートを切断してから，さらにホットプレス成形装置を使 用し, 試験板を所望の厚さに応じたスペーサーを使い, 積層 成形した。

最初のプリプレグ成形と試験片成形の工程方法は同一で, その方法を以下に説明する. シートをホットプレッス装置の 下部プランジャーに置いてから, 加熱装置のスイッチを入れ, シートの温度が $150{ }^{\circ} \mathrm{C} に$ 達するまで熱を加える. その後, 脱 泡および緎維間の樹脂の含浸を促進させるよう, 最初にプレ ス上下プランジャーが接触する程度のわずかな圧力を 30 分 かけてから, $4.9 \mathrm{MPa}$ の圧力を加え, 約 $0.5^{\circ} \mathrm{C} / \mathrm{min}$ の速度で $150{ }^{\circ} \mathrm{C}$ から常温まで冷却した。成形工程図を Fig. 6 に示す.

バサルトロービングを使用して一方向強化の試験片を成形 し，またバサルト平織クロスから二方向強化試験片を成形し た. 最初に, 基準の加工パラメータ（温度： $150{ }^{\circ} \mathrm{C}$, 圧力： $4.9 \mathrm{MPa}$ )で一方向強化の引張試験片および曲げ試験片を製作 した.さらにプリプレグ成形加工パラメータの機械的特性へ の影響を検討するため, 引張試験片のプリプレグ積層成形加

Table 3 Processing parameters for tensile test specimen production.

\begin{tabular}{l|l|l|l|l|l|l|l|l}
\hline Fibre type & \multicolumn{3}{|c|}{ Basalt roving (BS-13-1200) } & \multicolumn{3}{|c|}{ Basalt fabric (BT-8) } \\
\hline Prepreg moulding temperature $\left[{ }^{\circ} \mathrm{C}\right]$ & 130 & 150 & 170 & 150 & \multicolumn{3}{|c|}{150} \\
\hline Prepreg moulding pressure [MPa] & 4.9 & 4.9 & 4.9 & 9.8 & \multicolumn{3}{|c|}{4.9} \\
\hline Sample moulding temperature $\left[{ }^{\circ} \mathrm{C}\right]$ & \multicolumn{3}{|c|}{150} & \multicolumn{3}{|c|}{150} \\
\hline Sample moulding pressure [MPa] & \multicolumn{3}{|c|}{4.9} & \multicolumn{3}{|c|}{4.9} \\
\hline Number of prepreg-sheet layers [1] & \multicolumn{3}{|c|}{4} & 4 & 5 & 6 & 7 \\
\hline
\end{tabular}

Table 4 Processing parameters for flexural test specimen production.

\begin{tabular}{l|c|c|c|c|c|c}
\hline Fibre type & Basalt roving (BS-13-1200) & \multicolumn{4}{|c}{ Basalt fabric (BT-8) } \\
\hline Prepreg moulding temperature $\left[{ }^{\circ} \mathrm{C}\right]$ & 150 & \multicolumn{4}{|c}{150} \\
\hline Prepreg moulding pressure $[\mathrm{MPa}]$ & 4.9 & \multicolumn{4}{|c|}{4.9} \\
\hline Sample moulding temperature $\left[{ }^{\circ} \mathrm{C}\right]$ & 150 & \multicolumn{4}{|c|}{150} \\
\hline Sample moulding pressure $[\mathrm{MPa}]$ & 4.9 & \multicolumn{5}{|c|}{4.9} \\
\hline Number of prepreg-sheet layers $[1]$ & 8 & 6 & 8 & 9 & 10 & 12 \\
\hline
\end{tabular}

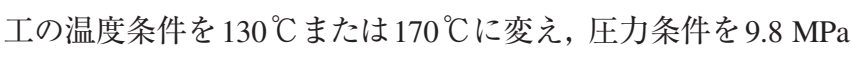
に変化させた。一方向引張試験片は 4 枚のプリプレグシート を積層成形し，曲げ試験片製作にはプリプレグシートを 8 枚 積層した。

繊維含有率の機械的特性への影響を測定するため，平織ク ロス強化複合材料の試験片を種々のシートの枚数で成形し た。引張試験片の成形に4枚から 7 枚までのプリプレグシー トを使い, 曲げ試験片の場合, シートの枚数を 6 枚から 12 枚 まで変化させた，全ての二方向試験片とも，基準の加工パラ メータの下で作製した. Table 3 およびTable 4は全ての加工 パラメータをまとめたものである.

\section{4 引張試験}

引張試験をJIS K 7113 に基づき実施した。試験片の寸法は 長さ $200 \mathrm{~mm}$, 幅 $10 \mathrm{~mm}$, 厚さ $1 \mathrm{~mm}$ である.引張試験機は Instron万能材料試験機, モデル 4200 を用いた。試験はひず み速度 $1.0 \mathrm{~mm} / \mathrm{min}$ で実施した。試験片端部にガラス繊維強 化エポキシを接着剤により固着することによりチャック部を 補強した。試験中で荷重を接続したコンピュータシステムに よって記録し，ひずみをひずみゲージによって測定した。

\section{5 曲げ試験}

曲げ特性をJIS K 7017 に基づいて実施された 3 点曲げ試験 結果から評価した. 試験片の寸法は長さ $60 \mathrm{~mm}$, 幅 $15 \mathrm{~mm}$, 厚さ $2 \mathrm{~mm}$ である. 曲げ試験機は島津 AGS-1000B 万能材料試 験機を用いた。試験は試験速度 $1.0 \mathrm{~mm} / \mathrm{min}$ で実施した。曲 げ弾性率 $E_{f}$ を式(1)よって計算した。

$$
\begin{aligned}
& E_{f}=\frac{L^{3}}{4 b h^{3}}\left(\frac{\Delta F}{\Delta S}\right) \\
& \Delta S=S^{\prime \prime}-S^{\prime}=\frac{\varepsilon_{f}^{\prime \prime} L^{2}}{6 h}-\frac{\varepsilon_{f}^{\prime} L^{2}}{6 h}=\frac{0.0025 L^{2}}{6 h}-\frac{0.0005 L^{2}}{6 h} \\
& \Delta F=F^{\prime \prime}-F^{\prime}
\end{aligned}
$$

ここで， $b, h$ はそれぞれ試験片の幅と厚さ，Lは支点距離 間， $S$ はたわみ， $F_{m}$ は最大荷重である. $\Delta S$ 及び $\Delta F$ をそれぞ

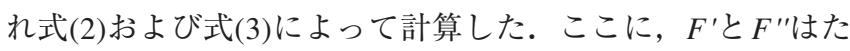

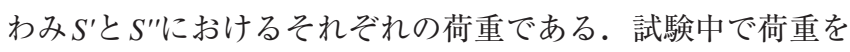
接続したコンピュータシステムによって記録し，ひずみをひ ずみゲージによって測定した。

\section{6 組織観察}

試験後の破壊の様子を, 走査電子顕微鏡（日立S-2100 A) を 用いて観察した. 観察前に試験片表面部の金蒸着を行なった.

\section{3. 試験結果}

\section{1 一方向バサルト繊維強化グリーンコンポジッ 卜の機械的特性}

基準の加工パラメータ, $150{ }^{\circ} \mathrm{C}$ と $4.9 \mathrm{MPa}$ にって成形し 
Table 5 Mechanical properties of unidirectional reinforced composite.

\begin{tabular}{l|c}
\hline Moulding pressure [MPa] & 4.9 \\
\hline Moulding temperature [ $\left.{ }^{\circ} \mathrm{C}\right]$ & 150 \\
\hline Fibre volume fraction [\%] & 40 \\
\hline Tensile strength [MPa] & 517 \\
\hline Elongation at break [\%] & 2.0 \\
\hline Modulus of elasticity [GPa] & 31.8 \\
\hline Flexural strength [MPa] & 157 \\
\hline Flexural modulus [GPa] & 16.9 \\
\hline
\end{tabular}

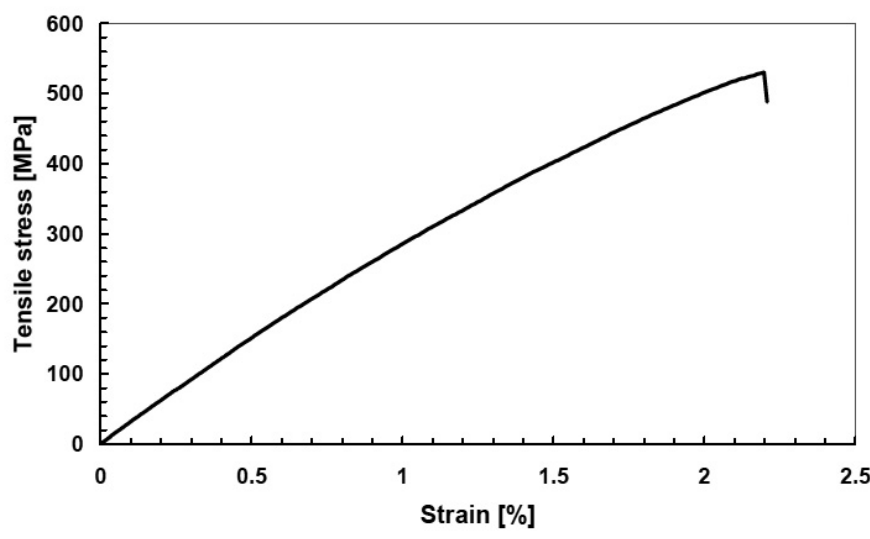

(a) Tensile stress-strain diagram

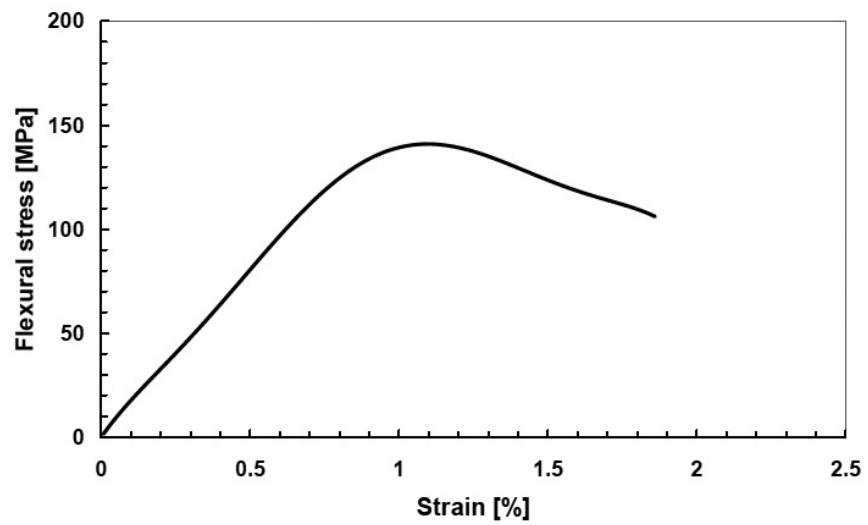

(b) Flexural stress-strain diagram

Fig. 7 Typical stress-strain diagrams of unidirectional reinforced composites with $40 \%$ volume fibre fraction.

た試験片の引張強度及び曲げ強度の測定の結果, 平均值を Table 5 に示し, Fig. 7 に典型的な応力ひずみ線図を示す.

長繊維強化複合材料の場合，最終破断応力 $\sigma_{1 \mathrm{c}}$ は複合則に よって次のように表すことができる[17].

$\sigma_{1 c}=\left(1-V_{f}\right) \sigma_{1 m}+V_{f} \sigma_{1 f}$

また，複合材料の引張弾性率は次式で与えられる。

$E_{1 c}=\left(1-V_{f}\right) E_{m}+V_{f} E_{f}$

$\sigma, E, V$ はそれぞれ最終破断応力 (引張強度), 引張弾性 率及び繊維体積含有率であり， $c, m, f, 1$ の添字記号はそれ
ぞれ複合，マトリックス，繊維および引張方向を意味する.

複合則により，一方向複合材料の引張強度と引張弾性率を 計算した。計算に際して繊維引張強度 $\sigma_{1 f}$ おび繊維弾性率 $E_{f}$ は製造会社のカタログ值（1850 MPaおよび89 GPa）を使用 した。予測した引張強度及び引張弾性率はそれぞれ745.3 MPa と $35.8 \mathrm{GPa}$ である.引張試験で測定した引張弾性率の值は予 測した值の $89 \%$ となり，ほぼ理論值に近い值が得られた。一 方，測定した引張強度の值は予測した值をかなり下回り，理 論值の $69 \%$ である。

繊維を外部荷重と平行になるように成形時の繊維配向およ び試験機への試験片の取り付けには細心の注意を払ったが, 積層板の初期破壞は繊維に沿う縦方向の破壊，いわゆるスプ リッティング破壞が支配的であった（Fig. 8参照).

成形温度の一方向複合材料機械的特性に及ぼす影響を Fig. 9 に示す。引張強度および引張弾性率はともに成形温度が $150{ }^{\circ} \mathrm{C}$ のきに明確に最大となった。このことより引張強度 および引張弾性率の観点から，本材料の成形温度の最適值は

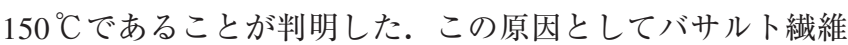
とマトリックスの熱膨張係数の相違に基づいて，成形過程に 生じる残留応力などが関係するものと考えられるが，詳細な 検討については，今後の研究課題としたい.

成形圧力の一方向複合材料機械的特性に及ぼす影響を Fig. 10 に示す. 加工圧力 $4.9 \mathrm{MPa}$ から $9.8 \mathrm{MPa}$ へ上昇は, 引張強 度の低下を導いた。この原因は増加した圧力により繊維配向

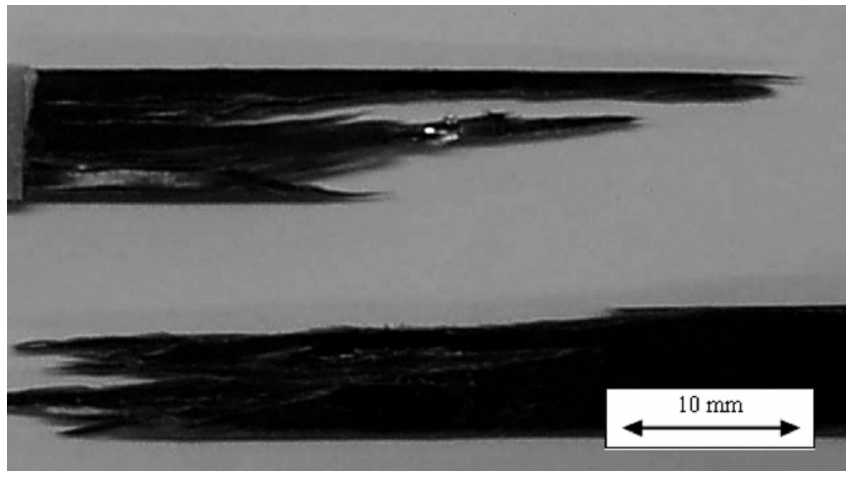

Fig. 8 Fractural behaviour of unidirectional composite.

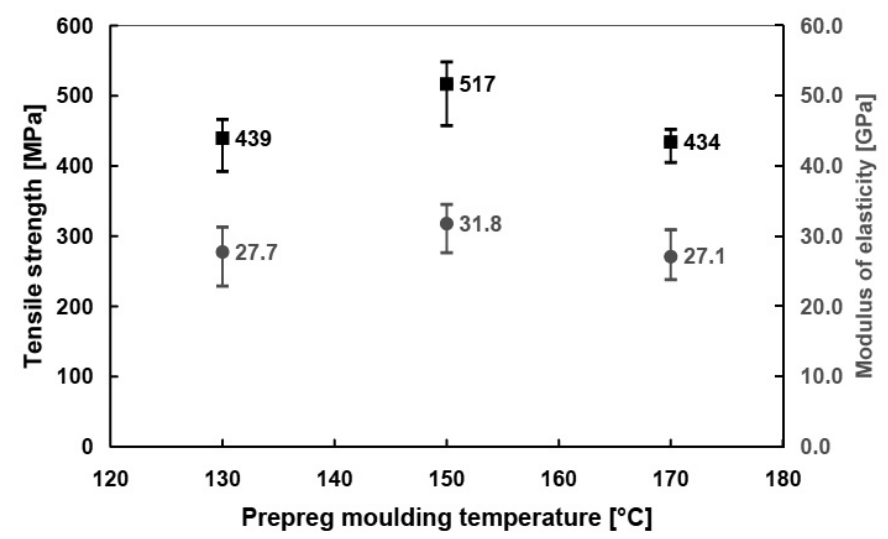

Fig. 9 Effect of the processing temperature on the tensile properties of unidirectional composites. 


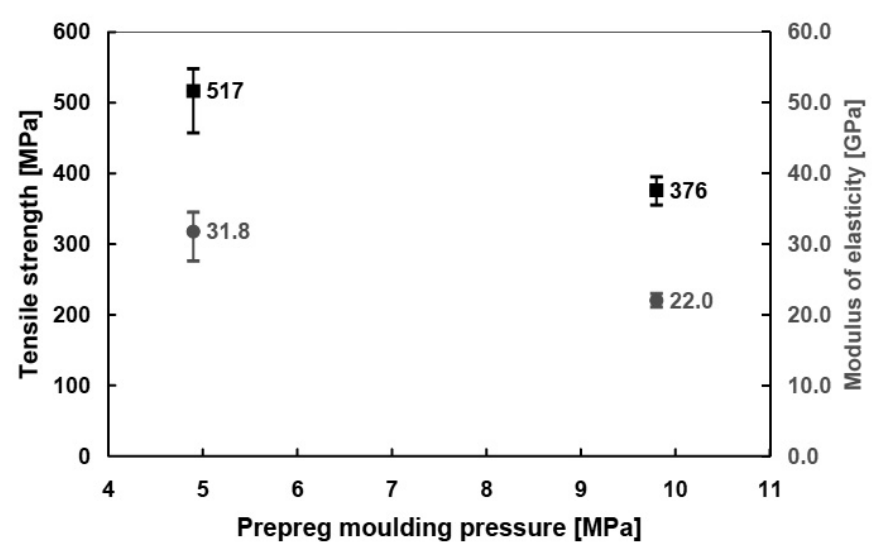

Fig. 10 Effect of the processing pressure on the tensile properties of unidirectional composites.

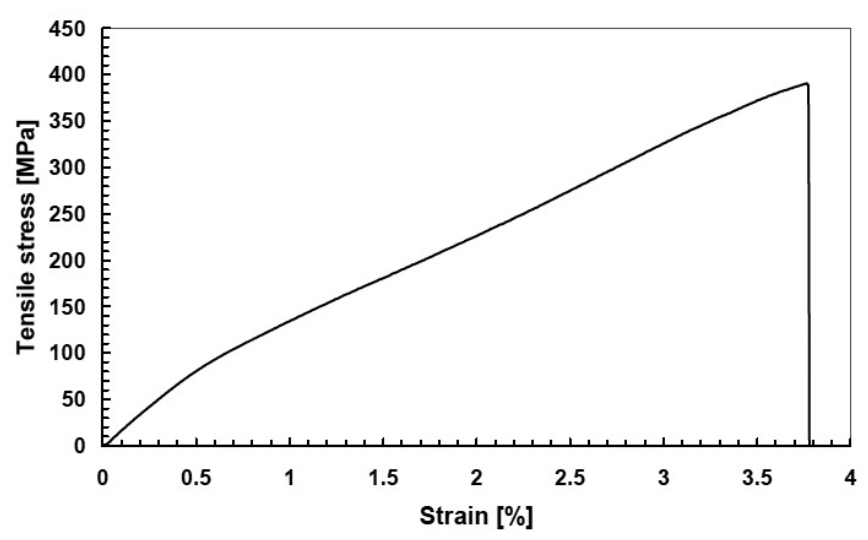

(a) Tensile stress-strain diagram $\left(V_{f}=61 \%\right)$

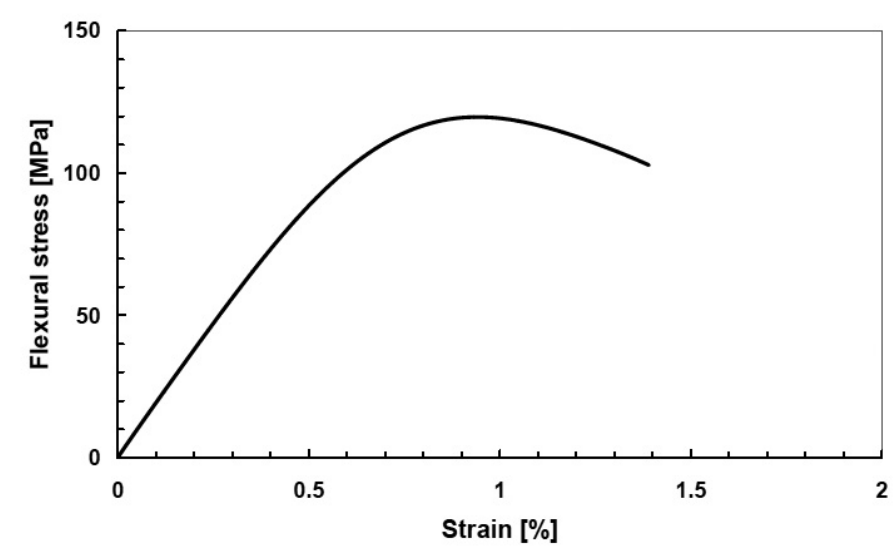

(b) Flexural stress-strain diagram $\left(V_{f}=42 \%\right)$

Fig. 11 Typical stress-strain diagrams of plain weave reinforced composites.

のズレが生じたためであると思われる.

以上の結果に基づき， $150{ }^{\circ} \mathrm{C}$ 及び $4.9 \mathrm{MPa}$ をその後の試験 片成形のための基準加工パラメータとして選んだ.

\section{2 二方向バサルト平織クロス強化グリーンコン ポジットの機械的特性}

Fig. 11 に平織クロス強化複合材料の典型的な引張および曲 げ応力ひずみ線図を示す.バサルト平織クロスを使用し，60\%

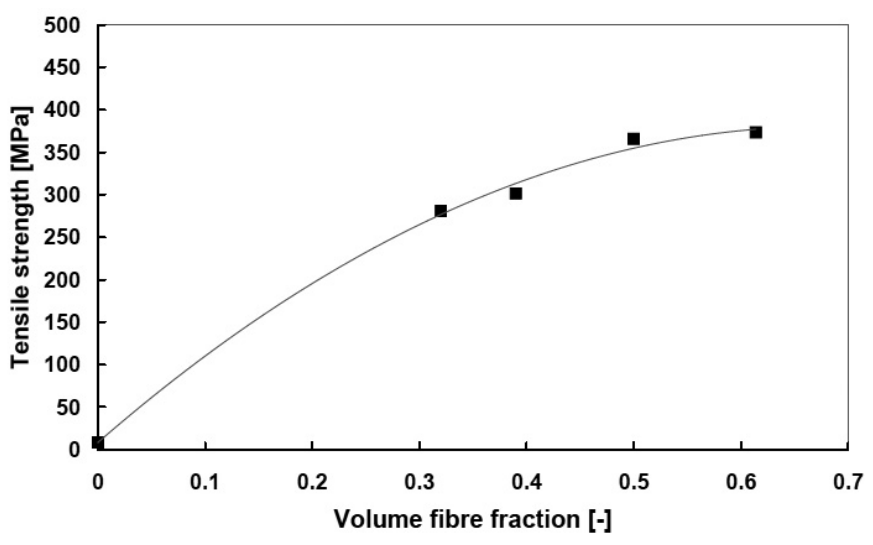

(a) Tensile strength versus volume fibre fraction

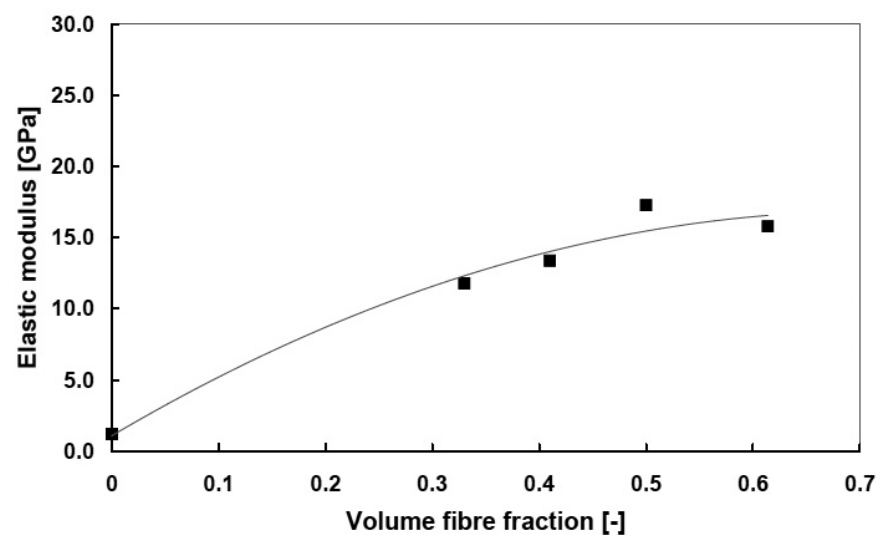

(b) Elastic modulus versus volume fibre fraction

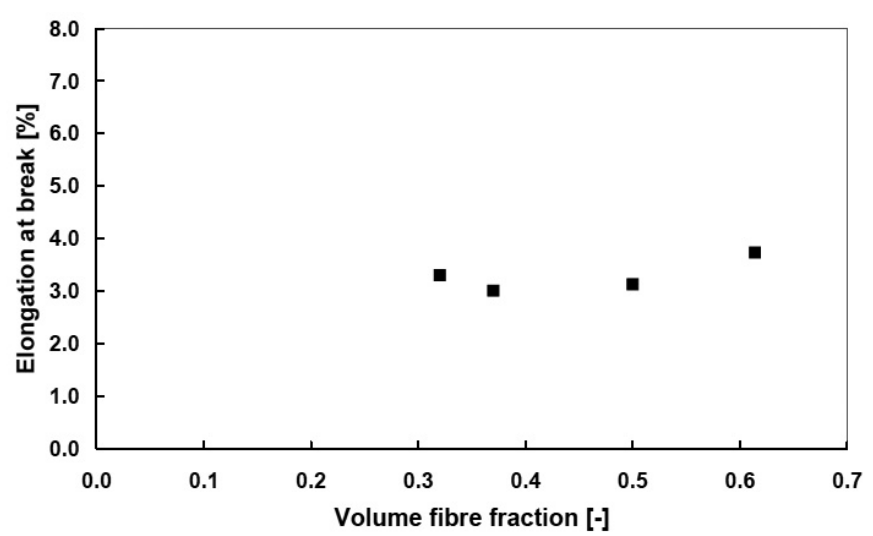

(c) Elongation at break versus volume fibre fraction

Fig. 12 Tensile properties of plain weave reinforced composite depending on fibre volume fraction.

までの繊維体積含有率を有する高強度の直交異方性グリーン コンポジットを成形することに成功した。グリーンコンポジッ 卜の最大平均引張強度および曲げ強度はそれぞれ $373 \mathrm{MPa}$ よび $122 \mathrm{MPa}$ である。

Fig. 12(a)および(b)に平織クロス強化複合材料の各種繊維 体積含有率に対する引張強度および引張弾性率を示す。

複合材料の引張強度は $32 \%$ の繊維体積含有率で $281 \mathrm{MPa}$ の 值に達した。 $50 \%$ の繊維体積含有率の引張強度は366 MPaま で上昇するが，さらに繊維体積含有率を $61 \%$ まで上昇させて も引張強度は $373 \mathrm{MPa}$ の平均值でほとんど変化しない。 


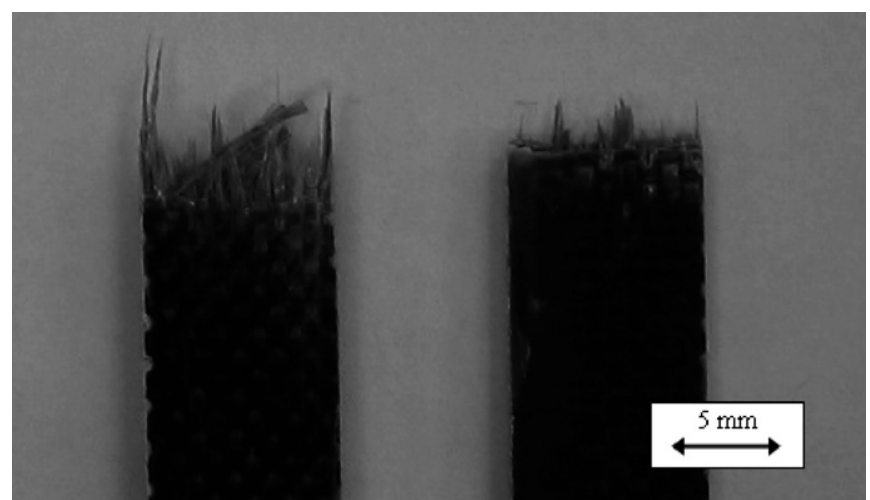

Fig. 13 Fracture behaviour of plain weave reinforced composite specimens; left: $V_{f}=50 \%$, right: $V_{f}=33 \%$.

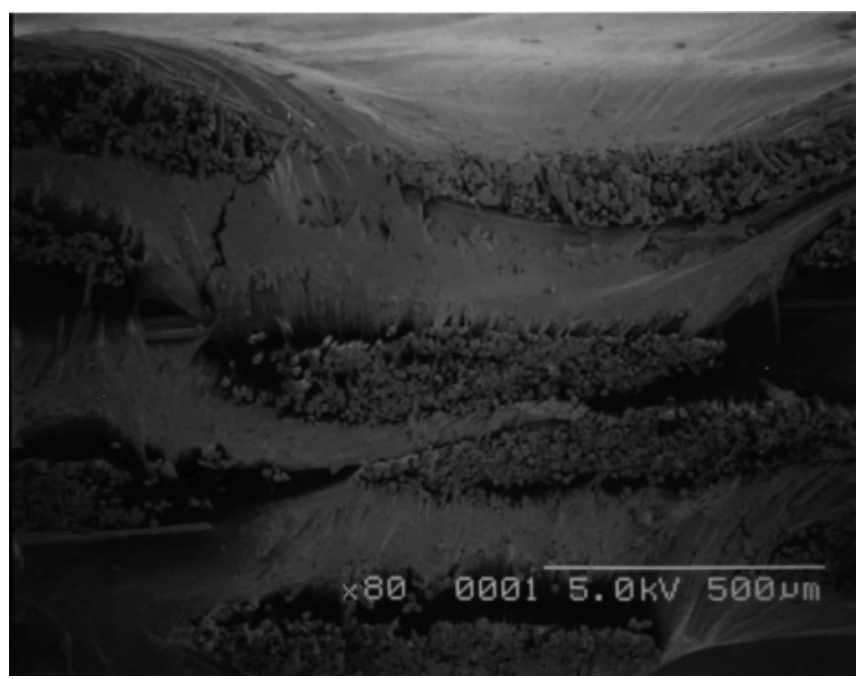

Fig. 14 SEM micrograph of the fracture surface of a plain weave reinforced composite with $V_{f}=50 \%$.

上記の現象を繊維のぬれ性の観点から説明することとす る。一般的に繊維含有率が上昇するにつれ，繊維のぬれが悪 化する. Fig. 13に示すように，䋊維体積含有率が $33 \%$ と $50 \%$ の試験片の破壊挙動を比較すると，前者の場合，引張荷重と 垂直方向で直線的な破面を示すのに対し，後者は繊維引抜き を伴う刷毛状外観の破面を呈した. 繊維・樹脂間のぬれの低 下, 言い換えると, 繊維・マトリックス間の界面接着強度の低 下している様子が50\%試験片の破面の走査電顕写真 (Fig. 14) から観察される．樹脂は繊維束の中に充分に含浸されず，充 分な繊維・マトリックス間の接着は繊維束の外部のみに生じ るため, 繊維束の内部の繊維はお互いに触れ合う状態にある. 繊維引抜きはその結果であると考えられる. また, 走査電顕 写真観察から, 比較的高いボイド量の存在が認められる. ボ イドの存在は複合材料の剥離及び初期破壊の原因となるゆ え，ボイド量をいかに減少させるかも今後の課題である.

引張弾性率の繊維体積含有率の変化に対する挙動は引張強 度の挙動に類似している。䋊維含有率が $32 \%$ の場合に 11.8 $\mathrm{GPa}$ 測定された弾性率值は, 繊維体積含有率が $50 \%$ に増加 することにより，17.3 GPaまで上昇したが，纎維体積含有率 が $61 \%$ の場合には弾性率值は $15.8 \mathrm{GPa}$ に低下した。この原 因として, 高いボイド率, 繊維束内への不十分なマトリックス

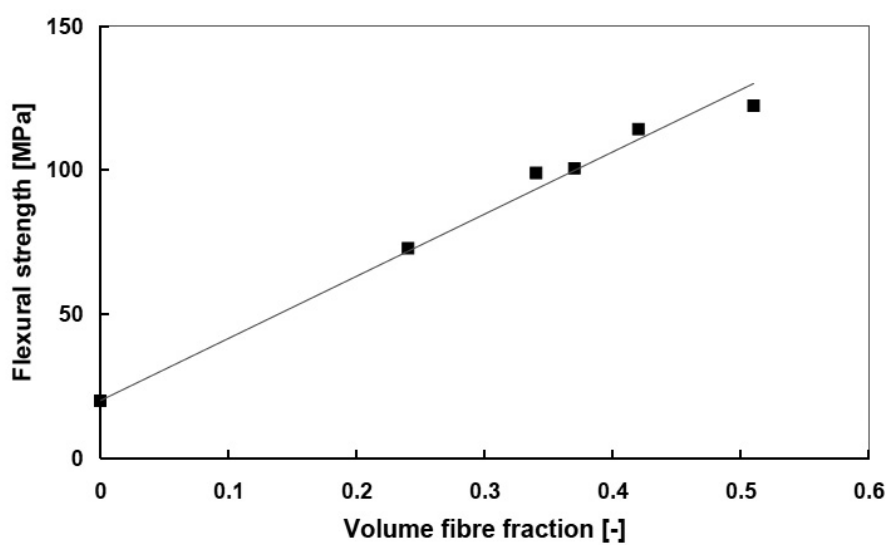

(a) Flexural strength versus volume fibre fraction

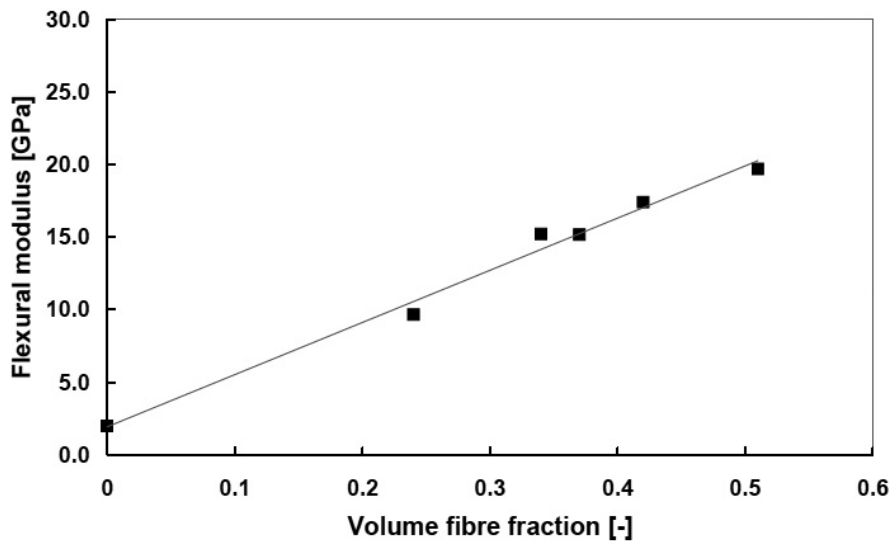

(b) Flexural modulus versus volume fibre fraction

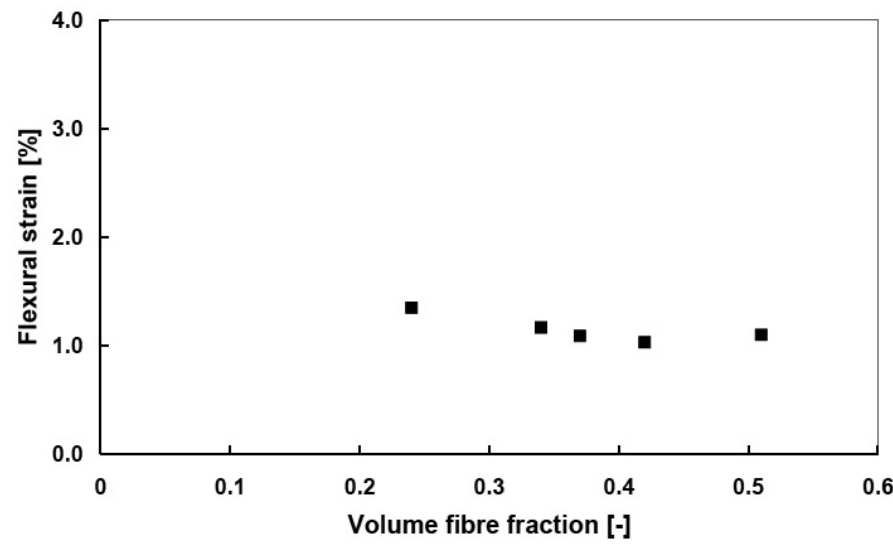

(c) Flexural strain versus volume fibre fraction

Fig. 15 Flexural properties of plain weave reinforced composite depending on fibre volume fraction.

の含浸とそれに起因する層間剪断強度の低下が考えられる。

繊維体積含有率に対する破断伸びを表す Fig. 12 (c)から， 破断伸びの值は繊維含有率に依存しないことがわかる。 $61 \%$ の含有率で得た $3.74 \%$ の破断伸び最大值は, 報告されている 単繊維の破断伸び值をわずかに上回るものである。この挙動 は繊維が主な載荷成分であることを示し，高繊維含有率にお いてより高い破断伸びの值が得るためには，繊維・マトリッ クス接着強度の改善により繊維・マトリックス間の応力伝達 能力を向上させることが重要であることを示唆している。

繊維体積含有率に対する曲げ強度, 曲げ弾性率および最大 応力時の曲げひずみを Fig. 15 に示す。強度および弾性率の值 


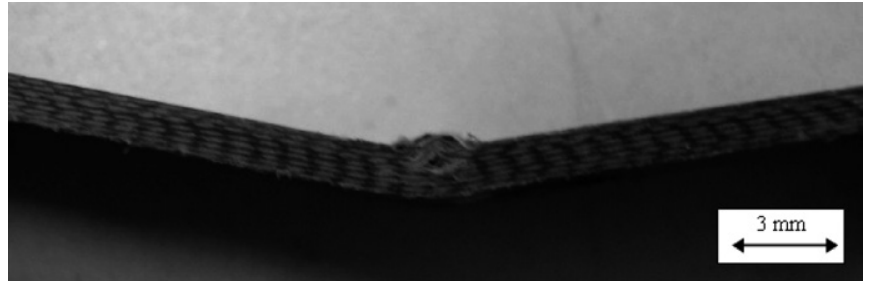

Fig. 16 Flexural failure mode of basalt plain weave reinforced composite.

は繊維含有率の増加とともにほぼ直線的に上昇した。曲げ強 度の值は繊維体積含有率が $24 \%$ のとに $73 \mathrm{MPa}$ であり, $51 \%$ のきには $121 \mathrm{MPa}$ まで上昇した. また同じ含有率の範囲 で, 弾性率は $9.7 \mathrm{GPa} ら 19.7 \mathrm{GPa}$ に上昇した. なお, 繊維含 有率の増加に伴い， $1.35 \%$ と $1.03 \%$ 範囲における曲げひず み值の減少傾向に指示される曲げ剛性の上昇が観察された.

3 点曲げ試験の間, 試験片の下層は引張を受け, 上層は圧 縮を受ける。Fig. 16からわかるよう，全ての曲げ試験片は， 上層における圧縮に伴う繊維の座屈が起因となり, 最終的に は圧縮破壊を示した。座屈荷重下においては繊維は主に周囲 のマトリックスによって支持・拘束されるので，樹脂特性及 び繊維・マトリックス接着強度に依存することは明確であ る. 剥離は座屈損傷を起こしやすいため, 界面接着強度の改 善は曲げ特性の改善にキーとなるものと考えられる。

\section{4. 結 言}

本研究において，はじめにバサルト繊維強化澱粉樹脂プリ プレグシートを成形した. プリプレグを使用し成形した積層複 合材料の機械的特性を測定した結果，以下のことが判明した。 (1) バサルトロービングおよび平織バサルトクロスを澱粉樹 脂と組み合わせ，ドクターブレード装置およびホットプレッ ス装置を使用し, 繊維执よびマトリックスとも天然素材の高 強度一方向グリーンコンポジットおよび高強度二方向グリー ンコンポジットの成形に成功した。

(2) ドクターブレード装置の適用により成形工程を機械化す ることができた。

（3）繊維体積含有率の変化に伴う機械的特性挙動を分析し, 引張強度と曲げ強度及びそれぞれの弾性率が, 含有率の増加 とともに改善することを確認した。一方, ひずみ挙動は繊維 含有率にほとんど依存していない結果となった。この原因と して, 高いボイド率, 繊維束内への不十分なマトリックスの 含浸とそれに起因する層間剪断強度の低下が考えられる。高 い繊維体積含有率の場合, 樹脂は繊維束の中に充分に含浸さ れず, 充分な繊維・マトリックス間の接着は繊維束の外部の みに生じるため, 繊維束の内部の繊維は打互いに触れ合う状 態にある.引張試験における繊維引抜きはその結果であると 考えられる. また, 引張試験後の走査電顕写真観察から, 比 較的高いボイド量の存在が認められた. ボイドの存在は複合 材料の剥離及び初期破壊の原因となるゆえ, ボイド量をいか に減少させるかが重要である, 全ての曲げ試験に扎いて, 試 験片の上層における圧縮に伴う繊維の座屈が起因となり, 最 終的には圧縮破壊を示した。座屈荷重下に打いては繊維は主 に周囲のマトリックスによって支持・拘束されるので, 樹脂
特性及び繊維・マトリックス接着強度に依存することは明確 である、剥離は座屈損傷を起こしやすいため, 界面接着強度 の改善は曲げ特性の改善のキーとなるものと考えられる.

天然バサルト繊維は優れた機械的特性及び低い環境負荷軽 減効果が期待できるゆえ，グリーンコンポジット用の強化繊 維材として将来有望であると考えている. 本研究のために成 形したバサルト繊維強化グリーンコンポジットは，最も広沉 に使用されているガラス繊維強化プラスチックスと同等の機 械的特性を示すことが明らかになった。さらに機械的特性を 向上させる見地から繊維・マトリックス間の界面特性および 繊維のぬれ性を改善が重要であり，バサルト繊維に適した繊 維表面処理方法の探究が求められる。現在，これに関して研 究を進めているところである。バサルト繊維を用いて環境に やさしいグリーンコンポジットの開発を目指して, 更なる成 形工程の最適化，他の種類の生分解性樹脂との組み合わせな どについて今後研究を進めたいと考える.

\section{References}

[1] Hughes M (2004) "Green composites: Polymer composites and the environment", Chap 11, Woodhead Publishing, Cambridge

[2] Sain M, Panthapulakkal S (2004) "Green composites: Polymer composites and the environment", Chap 9, Woodhead Publishing, Cambridge

[3] Chiou BS, Glenn GM, Imam SH, Inglesby MK, Wood DH, Orts WJ (2005) "Natural Fibers, Biopolymers and Biocomposites", Chap 20, Taylor \& Francis, Boca Raton

[4] Tanaka H (2003), Eng Mater, 51, 58-62

[5] Ochi S, Takagi H, Tanaka H (2003) J Soc Mat Sci Japan, 52, 857-862

[6] Gomes A, Goda K, Ohgi J (2004) JSME Int J Ser. A, 47, 541-546

[7] Stamboulis A, Baille C, Peijs T (2001) Composites A, 32, 1105-1115

[8] Militky J, Kovacic V (1996) Tex Res J, 66, 225-229

[9] Dzhigiris DZ, Makhova MF, Gorobinskaya VD, Bombyr LN (1983) Glass and Ceramics, 40, 467-470

[10] Morozov NN, Bakunov VS, Morozov EN, Aslanova LG, Granovskii PA, Prokshin VV, Zemlyanitsyn AA (2001) Glass and Ceramics, 58, 100-104

[11] Sokolinskaya MA, Zabava LK, Tsybulya TM, Medvedev AA (1991) Glass and Ceramics, 48, 435-437

[12] Gur'ev VV, Neproshin EI, Mostovoi GE (2001) Glass and Ceramics, 58, 62-65

[13] Kogan FM, Nikitina OV (1994) Env Health Persp, 102 Suppl 5, 205-206

[14] Matthews FL, Rawlings RD (1994) "Composite Materials: Engineering and Science", Chapman \& Hall, London

[15] Nanjyo N (2007) J Jpn Soc Comp Mater, 33, 141-149

[16] Mohanty AK, Misra M, Hinrichsen G (2000) Macromol Mater Engin, 276/277, 1-24

[17] Hull D (1981) "An introduction to composite materials", Cambridge University Press, Cambridge 